\title{
Here to stay? The rapid evolution of the temporary staffing market in Iceland
}

\author{
Gylfi Magnússon, Associate Professor, University of Iceland \\ Inga Minelgaite, Assistant Professor, University of Iceland \\ Erla S. Kristjánsdóttir, Associate Professor, University of Iceland \\ Póra H. Christiansen, Adjunct Lecturer, University of Iceland
}

\begin{abstract}
In recent years there has been a significant shortage of workers in Iceland. The traditional method of arranging temporary work, through direct contracts between employees and employers, has not sufficed. Moreover, there is a skills mismatch that compounds the shortage of workers as the sectors that have grown most rapidly in recent years mainly employ unskilled labor. This study examined the historical background of temporary work in Iceland, recent developments and in particular the growing importance of temporary staffing agencies, as well as the economic rationale for temporary staffing agencies, and the segmented labor market in Iceland. The study employs expert opinion approach, together with content and statistical analysis. Experts placed strongest emphasis on temporary workforce dependency on economic conditions, closely followed by sector triggered temporary workforce fluctuation. Socio-legal infrastructure for temporary workforce had the third strongest emphasis with other themes being less emphasized. These dramatic changes to the Icelandic labor market have undoubtedly had a significant impact on Icelandic society but there is surprisingly little research available into this. The efforts of unions and the Federation of Employees have helped to push through legislation on temporary staffing agencies and the rights of foreign workers, however, as long as there is economic rationale for their operation and a legal and regulatory framework that accommodates them
\end{abstract}

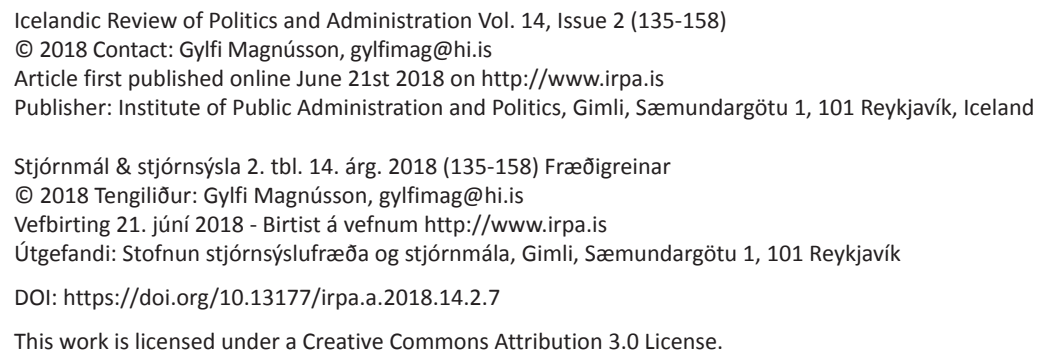


the agencies can be expected to continue bringing temporary staff to Iceland. The impact on the labor market and society thus seems likely to be permanent.

Keywords: Temporary staffing industry; agency; labor market; fixed term; employees.

\section{Introduction}

Temporary work has historically been common in Iceland but has been based on a direct contractual relationship between each employer and his employees with no agency acting as an intermediary. Industries such as fishing and fish processing have relied on such access to temporary workers, laying them off when they are not needed and then rehiring when the need rises again. However, the traditional method of temporary work, through direct contracts between employees and employers is not sufficient to meet the rapidly growing demand at present, especially for both skilled and unskilled labor in the rebounding construction sector and the booming tourism sector (ASÍ 2018).

There is a significant shortage of workers in Iceland. ${ }^{1}$ The sectors of the economy that have grown most rapidly in recent years mainly employ unskilled labor or workers with vocational training, e.g. carpenters, electricians and plumbers in the construction sector or chefs, bus drivers in the tourism sector (ASÍ 2018). However, education levels have been rising significantly for the local population. The number of people with university degrees has grown from 11.1\% of the labor force in 1991 to 35.6\% in 2016 (Statistics Iceland n.d.). Thus, there is a skills mismatch that compounds the shortage of workers. This need for employees has opened up the market for new forms of employment such as temporary jobs and temporary staffing agencies (TSAs).

The increased importance of TSAs is not unique; a similar development has taken place in many countries in Western Europe in the last 10-15 years or so although the pace differs from one country to another (Eurofound 2015). Eichhorst (2015) notes that in Germany "policies to deregulate the margin of the labour market — and activation policies, at least to some extent — have opened up a segment of cheaper and more flexible types of work, in particular agency work, fixed-term employment, and freelance and part-time, most notably marginal part-time work" (p. 65). However, in Iceland the TSAs started playing a significant role fairly recently, in the economic boom that preceded the crisis of 2008 and then again as the economy recovered after the crisis. ${ }^{2}$

The main objective of this study is to map the development of the temporary staffing market in Iceland, as well as obtain insights into its development for the future. The research question is: How has the Icelandic temporary staffing market developed and what are the future prospects? This paper investigates the historical background of temporary work in Iceland, examines the growing importance of TSAs, provides an overview of temporary workers and posted workers, states the economic rationale for TSAs, and explores the segmented labor market in Iceland. In sum, the article provides an overview of important contemporary phenomena within Icelandic society, which have not yet been addressed by research in an integrated way. Moreover, an expert opinion research approach, employing content analysis together with statistical calculations was used in this 


\section{STJÓRNMÁL \& \\ STJÓRNSÝSLA}

paper for conveying relevant and timely information about the past, present and future trends for this new phenomenon in Icelandic society. Finally, a discussion of the main results, conclusion and suggestions for future research are presented.

\section{Historical background}

For centuries the Icelandic economy was agriculture based with highly cyclical demand for labor. With few working in other sectors there was, however, little flexibility in the supply of labor to the agricultural sector, except in the number of hours worked each day and in the participation rate of children in farm work. The development of another main sector, fisheries, meant that to some extent workers could shift between these two sectors depending on the need for labor in each. ${ }^{3}$

With the growth of other sectors, most importantly the service sector, in particular in the 20th century, more flexibility in shifting labor supply from one sector to another was possible. The expansion of the educational system also meant that students and teachers that spent winters studying or teaching were available as workers during the summer. This suited the agricultural sector well but also other sectors with a heavy demand for workers during the summertime, such as construction, road building and eventually tourism. In addition, it has been quite common for Icelandic students to work part-time in temporary jobs during the school year, thus providing a fairly flexible supply of labor suitable for entry-level jobs. ${ }^{4}$

All these factors, and others, have meant that the Icelandic labor market has been quite flexible and able to adjust to fluctuations in local demand for labor. Historically it has however not been well connected with the labor markets in neighboring countries. Some emigration, notably to North-America in the 19th century, was the main exception. For most of the 20th century foreigners faced significant hurdles if they wanted to participate in the Icelandic labor market. Immigration was curtailed by law and in practice quite limited. The main exception was that citizens of the Nordic countries could move relatively freely from one country to another. Few used this opportunity to move to Iceland but Icelanders were more likely to benefit from this by working for a while in the other Nordic countries or even migrating there. ${ }^{5}$

When the agreement on the European Economic Area came into effect in 1994 the Icelandic labor market became integrated with the far larger labor market of the European Union. It did not take long for this to fundamentally change the Icelandic market. In particular, it facilitated a substantial inflow of workers from countries in the European Union that offered lower wages than the Icelandic market. The largest number came from Poland but significant numbers came from other EU countries, including the Baltic states. At the end of 2017, Polish nationals were $5,9 \%$ of the total labor force in Iceland and 44,5\% of the foreign labor force in the country (Statistics Iceland n.d.).

An economic boom in the years 2002-2007 led to a massive increase in demand for construction workers, far beyond what the local population could supply. Foreigners also increasingly started working in the service sector, mainly as unskilled labor in low wage jobs. ${ }^{6}$ The Icelandic language knowledge as prerequisite in many service jobs 
means that they are not available to foreigners but jobs that do not call for much if any Icelandic are to an increasing degree filled by foreign workers. Cleaning services and most hotel work except front-end staff are an example of this. The limited pool of Icelandic speaking workers for some jobs has however meant that in recent years even front-end staff is increasingly hired despite limited or no skills in Icelandic. With most of the Icelandic customers willing and able to speak English (at e.g. restaurants or check-out counters in supermarkets) this trend has seemingly been quietly accepted by the local population for the most part.

Net migration of foreign nationals to Iceland was over 5,000 individuals in both 2006 and 2007, far more than Iceland had previously experienced. See also Fig. 1. The proportion of workers in the Icelandic labor market that were foreign nationals was under 5\% until early 2005 but then increased rapidly and peaked at $10 \%$ in the summer of 2008 (Statistics Iceland n.d.).



Figure 1. Net migration to Iceland 1961-2017

Source: Statistics Iceland n.d.

The financial crash of 2008 and the economic downturn that followed in 2009-2010 meant that the inflow of foreign workers to Iceland stopped and to some extent reversed, although the bulk of those that had come to Iceland during the boom stayed. The largest outflow was in 2009 which saw a net migration of 2,369 foreign nationals from Iceland. Unemployment in Iceland increased dramatically and locals in many cases looked for work abroad, in particular in Norway where wages were much higher than in Iceland at the time. ${ }^{7}$

With an improving economy after 2010 the migration pattern changed again. Since 
2012 there has been a positive flow of foreign nationals to Iceland, substantially greater than the small net outflow of Icelandic nationals. The proportion of workers in the Icelandic labor market that are foreign nationals fell from the $10 \%$ pre-crisis peak to a post-crisis low of $8 \%$ in 2012 but then started rising again and stood at an all-time high of $13.2 \%$ at the end of 2017. The number of foreign citizens living in Iceland grew by $76 \%$ in the period $2010-2017$, from 21,610 to 37,950 , an increase of $7.3 \%$ per year on average (Statistics Iceland and authors' calculations). See also Fig. 2.



Figure 2. The proportion of inhabitants of Iceland that are foreign citizens 2009-2018

Source: Statistics Iceland n.d.

The inflow of foreign workers to Iceland has in many cases been to meet a specific temporary need. A good example of this is two large interconnected projects in Eastern Iceland, the Kárahnjúkar power plant and Reyðarál aluminum plant. A large number of workers came to Iceland to work on these projects, often essentially brought here by the main contractors. The TSAs involved were based in Portugal but the workers included not only EEA nationals but also workers from outside the EEA, notably China. ${ }^{8}$ They then left after the completion of the projects. The novelty of having a large number of foreign workers employed in Iceland was a matter of concern for some and was discussed extensively in the media at the time. With practically no unemployment in the Icelandic labor market at the time the concerns about the impact on the local market were however limited. 
The inflow did though lead to some measures being taken by the government to regulate this market, in part due to pressure from Iceland's union sector. The Ministry of Social Affairs commissioned a detailed report on the legal status of TSAs (Blöndal 2005) and subsequently legislation on temporary work agencies was passed (no. 139/2005). In 2007 legislation was also passed (no. 45/2007) that was aimed at strengthening the rights of temporary workers that were sent to Iceland.

Furthermore, Iceland's Federation of Employees (ASÍ) and the Federation of Employers (SA) negotiated in 2004 a common understanding on issues regarding foreign workers in Iceland (ASÍ \& SA 2004). This common understanding was subsequently the basis of changes to Icelandic legislation on wages and pension rights (no. 145/2004, amending no. 55/1980). These changes were aimed at ensuring that the wages and rights of workers negotiated between Icelandic unions and employer associations would also apply to foreign workers (temporary or permanent).

Unions and the Federation of Employees were also vocal in pointing out the rights of foreign workers to the workers, their employers, agencies and others. The slogan 'Einn réttur - ekkert svindl!' (Common Rights - No Cheating!) was used for this purpose for several years pre-crisis and again post-crisis, starting in 2015.

In addition, Iceland's unions were active in monitoring the treatment of foreign workers, in part through workplace inspections, often demanding changes to pay or other factors. In April of this year the Federation of Employees and the Federation of Employers negotiated an agreement aimed in part at strengthening such monitoring (ASÍ \& SA 2018).

The unions have also for years actively lobbied for legislation establishing a chain of responsibility by contractors for the rights of workers that is not broken by the use of sub-contractors. Such legislation has not been passed but the current government has put a bill before parliament that would establish such a chain of responsibility (Parliamentary document 674 2017-2018).

\section{The growing importance of temporary staffing agencies}

Although long-term jobs have historically been more important than temporary work, the latter has played a significant role in many job markets. Many industries have cyclical or even fairly random need for labor. Relying solely on a fixed pool of workers with long-term contracts would be highly inefficient in such sectors.

TSAs have historically only played an insignificant role in Iceland. ${ }^{9}$ As stated above, temporary work has been common but mostly based on a direct contractual relationship between each employer and his employees with no agency acting as an intermediary. Often the same workers would return many times to temporary work for the same employer that had a cyclical need for workers. When not working for this employer the workers would either seek work elsewhere or stay out of the labor market, e.g. studying or working at home.

The economic boom that started as the economy recovered after the financial crisis increased the importance of TSAs and they gradually started playing a significant role 
in Iceland. The story is similar in the U.S., Katz and Krueger (2016) find that there has been a significant rise in the incidence of alternative work arrangements in the U.S. economy between 2005 and 2015. The percentage of workers in such arrangements (temporary help agency workers, on-call workers, contract workers, and independent contractors or freelancers) rose from 10.7\% in February 2005 to $15.8 \%$ in late 2015. The percentage of workers hired out through contract companies rose fastest, from $1.4 \%$ to $3.1 \%$ (ibid.). Similar growth has been seen in many countries, prompting studies of the development of temporary staffing industries in countries such as Australia (Coe, Johns \& Ward 2008), Germany (Ferreira 2016) and Norway (Jordhus-Lier, Coe \& Braten 2015).

The development started relatively late in Iceland but the number of workers employed through such agencies increased very rapidly when they had established a foothold in the country. In 2014 there were 4 TSAs operating in Iceland with only 22 workers. ${ }^{10}$ From this small base the industry took off and in 2017 there were 36 agencies and 3,205 workers.

In addition to the TSAs there were also bureaus that serviced so-called posted workers. ${ }^{11}$ The numbers for this sector grew similarly, from 5 bureaus servicing 91 workers in 2014, to 125 bureaus servicing 1,825 workers in 2017. See also Table 1.

Table 1. Temporary agency workers and posted workers 2014-2017

\begin{tabular}{lcrrrr}
\hline & 2014 & 2015 & 2016 & 2017 & Growth rate \\
\hline Temporary staffing agencies & 4 & 9 & 30 & 36 & $108.0 \%$ \\
Workers & 22 & 165 & 1,527 & 3,205 & $426.2 \%$ \\
\hline Service bureaus & 5 & 18 & 54 & 125 & $192.4 \%$ \\
Posted workers & 91 & 341 & 996 & 1,825 & $171.7 \%$ \\
\hline
\end{tabular}

Source: Directorate of Labor n.d.

As the figures in Table 1 show, the growth in this sector of the Icelandic labor market has been dramatic. To put the figures into perspective, the total number of individuals in the Icelandic labor market was estimated to be 196 thousand at the end of 2017, thereof 170 thousand Icelandic citizens and 26 thousand foreign citizens (Directorate of Labor n.d.).

The growth in this sector in Iceland took off later than in many other European countries. For example, Germany saw the penetration rate of TSA workers increase more than three-fold in the two decades leading up to 2014, or to 2.1 percent and at the same time the European average was 1.7 percent (Ferreira 2016). The current penetration rate in Iceland for TSA workers has risen to 1.8 percent from next to nothing in only four years.

In line with the Act on Temporary Work Agencies No. 139/2005 that came into 
effect on 1 February, 2006, all TSAs operating in Iceland must be registered with the Directorate of Labor, which notes whether the undertaking is Icelandic or foreign. While foreign agencies were most prevalent in the first wave of TSAs in the years before the economic crisis, Icelandic agencies have dominated the second wave, both in numbers, currently over two-to-one, and in operations, with 1,711 employees working for the Icelandic agencies and 50 employees for the foreign agencies at the end of December, 2017 (Directorate of Labor n.d.).

\section{Economic rationale for temporary staffing agencies}

The demand for temporary or posted workers has a seemingly fairly simple economic rationale. The traditional method of arranging for temporary work, through direct contracts between employees and employers has not been sufficient to meet the very rapid and volatile growth in demand, especially for both skilled and unskilled labor in the rebounding construction sector and the booming tourism sector. ${ }^{12}$ The rapid decline of unemployment in Iceland after the economic downturn in 2009-2010 played a significant role in this, with the average unemployment in the 12 months ending in November 2017 being only $2.1 \%$, thereof only $1.8 \%$ for Icelandic citizens (in 2009-2010 the figures were $8.3 \%$ and $7.8 \%$ respectively).

These unemployment figures essentially mean that there now is a significant shortage of workers. In this respect it also matters that education levels have been rising significantly for the local population and the number of people with university degrees has grown. The sectors of the economy that have grown most rapidly in recent years however employ mainly unskilled labor or workers with vocational training, e.g. carpenters, electricians and plumbers in the construction sector or chefs, bus drivers etc. in the tourism sector. There is therefore a skills mismatch that compounds the shortage of workers.

Furthermore, the temporary agencies also seem to be able to circumvent Iceland's minimum wage restrictions. ${ }^{13}$ There is clear evidence (ASÍ 2018) that in many cases workers coming to Iceland as posted workers or through TSAs get paid significantly less than the locals. This is not unique to the Icelandic job market but seems to be the rule in neighboring countries as well (Friberg 2013). Cash payments with little or no documentation facilitate this (and then payments of taxes or pension contributions are also suspect). Another well-known method is to understate the credentials of the workers, e.g. hiring a trained carpenter but listing him as an unskilled worker and paying him a corresponding wage. Finally, the Icelandic unions have claimed that even if the workers are being paid according to the minimum wages in the collective agreements, they are being paid under the market wages, which would make this a form of social dumping (Thorarins 2013).

In addition to being often paid less than the established minimum rate for their profession, which is illegal in Iceland, the workers in many cases have to pay very high fees for lodging (typically in cramped conditions, sometimes in unlicensed housing) that is arranged by their employer or TSA, pay service fees to the agencies and be billed for 
items such as work clothes or transport to and from work at fairly high rates (ASÍ 2018; RÚV 2017a). Anecdotes of harsh treatment are plenty. To give an example, in one case at least, temporary workers were billed far more for food in the workplace cafeteria than others (RÚV 2017b). The willingness of the foreign temporary workers to put up with such treatment presumably reflects a mixture of factors. Wages that are low by Icelandic standards may be high by their home country standards (and job opportunities there may be scarce) and workers that visit Iceland for a relatively short period, knowing no locals and not speaking Icelandic may not be well aware of what their rights are in the Icelandic labor market. Furthermore, they may fear losing their Icelandic job and being sent back home if they question their terms or treatment.

\section{A segmented labor market}

A recent survey ${ }^{14}$ of unionized workers strongly suggested that foreign workers in Iceland in general do worse than their native colleagues. They work longer hours on average (45 hours a week versus 41.5), their wages are lower (on average 445,216 ISK versus 481,921 in gross wages per month), they pay more for housing (31.3\% more per square meter when renting) and are less likely to benefit from government rent subsidies. In addition, labor market surveys systematically show a significantly higher unemployment rate for foreign nationals $(4.5 \%$ in 2017$)$ than Icelandic citizens $(1.8 \%)$. Foreigners also often find it hard to get their training or credentials from abroad accepted in Iceland, forcing them to accept jobs that pay less than those that they have trained for (Fréttablaðið 2014, 6). ${ }^{15}$ The temporary agency workers are thus in many ways on the fringe of society, with a lower standard of living than their colleagues, the trend noticed across many countries. For example, Gundert and Hohendanner (2014) found that in Germany temporary workers felt less affiliated to society than permanent workers.

With Poles being by a considerable margin the largest group of immigrants to Iceland it is though interesting that Poles in Reykjavík are better off in terms of access to regular employment and reduced risk of arbitrary and exploitative treatment than their compatriots in Oslo and Copenhagen. 80 percent of Polish migrants in Reykjavík are permanently employed by Icelandic companies, a much higher proportion than in Oslo (26\%) and Copenhagen (36\%) (Friberg et al. 2014). The same study furthermore finds that Polish subcontractor firms and various forms of self-employment were almost non-existent in Reykjavík at the time of the survey, which was conducted in 2010, before the dramatic rise in the number of TSAs and workers in Iceland. The authors find a significantly lower wage (in PLN) in Reykjavík than Oslo and Copenhagen at the time but this presumably reflects in part the very weak exchange rate of the ISK in 2010.

The willingness to come to Iceland to work despite the conditions and even discrimination described above reflects much higher wages, and in general a high standard of living, in Iceland than in the workers' home countries. Despite having to work harder for less pay than the locals in Iceland the foreign workers earn more than they would have at home. Those that stay in Iceland for a short period and then take their remaining earnings back home also benefit from the fact that Icelandic wages reflect the high cost 
of living in Iceland. This means that even relatively low wages by Icelandic standards can give the worker significant purchasing power when he is back home with his savings from the stay in Iceland.

There has been fragmented research into the effects of the rise of TSAs on job markets in recent years. One fundamental question that many have addressed is whether such work can be seen as a bridge or stepping stone into more permanent and better paid employment or whether workers risk being stuck in a sector with volatile employment and low wages. Jahn and Rosholm (2014) found that having agency work speeds up the transition into regular employment although the benefits differ across the groups that they analyze. They, however, also find that returning to a permanent job after a temp job may signal that the worker is of low ability and consequently depress wages. Jahn and Rosholm (2013) find that temporary work is a stepping stone into the regular labor market for immigrants to Denmark. Likewise, Faccini (2014) finds that that in most European countries temporary workers enjoy high rates of transition into permanent employment and that the increased use of such contracts in general reduces the unemployment rate.

To answer the need for further research into this rapidly growing industry, Coe and Ward (2014) have argued for studying the temporary staffing industry in the context of each national labor market. It is important to explore the role of the agencies as active agents in creating the temporary staffing market (Coe, Johns \& Ward 2009), as they have for example been found to shape migration through recruitment practices and promotion of certain groups as 'good workers' (Findlay, McCollum, Shubin, Apsite \& Krisjane 2013; MacKenzie \& Forde 2009), thus influencing both the client firms and the workers. Attention should also be paid to the influence of the state, unions and trade bodies (Ferreira 2016; Jordhuis-Lier, Coe \& Braten 2015) as differing regulations, union density and union responses to temporary agency migrations have been found to vary (Hardy, Eldring \& Schulten 2012). In the aim of gaining insight into the development of the temporary staffing market of Iceland, we pose the following research question: How has the Icelandic temporary staffing market developed and what are the future prospects?

\section{Methodology}

Expert opinion analysis is a well-established research method and is commonly used in healthcare and nursing research and economic forecasting, as well as in other study settings where there is a lack of appropriate information, needed to make decision, describe situation or development, and forecast the future events (Rowe \& Wright 2001). The research presented attempts to map the temporary staffing market developments in Iceland, providing a comprehensive overview that bridges the past, present and future. When considering research methods, several issues had to be addressed: 1) fragmented information on the temporary workforce in Iceland, 2) lack of up-to-date information, and 3) the need to forecast future developments in the temporary staffing market in Iceland. Consideration of the above led to the choice of the expert opinion research technique, as this research method addresses issues of insufficient available information, 
but more importantly, assumes a forecasting aspect with considerable precision (Rowe \& Wright 2001).

\subsection{Sample}

The expert-opinion method assumes that some people have more knowledge than others about a certain issue and hence, can provide various perspectives (Porter, Cunningham, Banks, Roper, Mason \& Rossini 2011). Anyone with relevant, extensive and indepth experience in relation to the topic of interest can be considered an expert, hence plurality in expertise should be sought in order to generate a range of insights (Krueger, Page, Hubacek, Smith \& Hiscock 2012).

Acknowledging these principles, as well as following guidelines provided by Mahmoud (n.d.), 12 experts were chosen as a sample for this expert opinion research. Diversity of expert backgrounds was considered in the selection process and included experts, such as: economists, business associations, NGOs, trade unions, and temporary workforce agencies. Experts were contacted via email, requesting their answers to three questions:

1. Could you describe your view on the development of the foreign workforce and temporary staffing agencies in Iceland?

2. How would you describe the current situation in the labor market? What is happening, changes in society, or changes in the economy?

3. How do you think the temporary staffing agency segment will develop in the future in Iceland? For the long term vs. short term, development, changes, challenges?

Ethical standards, as outlined by Bryman and Bell (2007) were considered and reflected in the text of invitations sent to experts.

\subsection{Data analysis methods}

In order to exploit the full potential of the expert opinion research technique and its mixed-method nature (Muskat, Blackman \& Muskat 2012), two phases of data analysis were employed in this research as described below.

\subsubsection{Qualitative content analysis}

All the answers to the questions received from 12 experts were analyzed. This content analysis was implemented by two independent peer-reviews, followed by comparative discussion (debriefing, as in Creswell 1998). As a result, seven themes were indicated in the expert opinion responses. These categories are (in random order): 1) Temporary workforce dependency on economic conditions, 2) Gender ratio in temporary workforce, 3) Sector triggered temporary workforce fluctuation, 4) Effects on housing/rental market, 5) Segregation of temporary workforce, 6) Expectations of temporary workforce employees, and 7) Socio-legal infrastructure for temporary workforce. 


\subsubsection{Statistical analysis of themes}

In line with the mixed-method nature of expert opinion research, we aimed not just to identify the themes from the content of data, but also to estimate statistically how strongly experts emphasized each theme. Each theme that was identified in the content analysis phase by an independent reviewer, was categorized on an ordinal variable (no/ small/large emphasis). Using this variable we calculated the inter-rater reliability within each theme (Gwet 2002). The strongest emphasis was on temporary workforce dependency on economic conditions (0.76), closely followed by the sector triggered temporary workforce fluctuation (0.66). Socio-legal infrastructure for temporary workforce $(0.38)$ had the third largest emphasis with other themes being less emphasized by experts (Effects on housing/ rental market, 0.21; Segregation of temporary workforce, 0.21; Gender ratio in temporary workforce, 0.12; Expectations of temporary workforce employees, 0.08).

One of the aims of the research was to determine how themes generated from the answers of the experts reflect developments in time - whether they were important in the past, present, or will be in the future (in line with three questions that experts were asked). Even though the research design is limited and does not enable us to calculate inter-reliability for each theme for all three time points, the descriptive statistics (Figure 3) allow us to indicate certain insights regarding the themes and how much they are emphasized in regard to past, present and future.

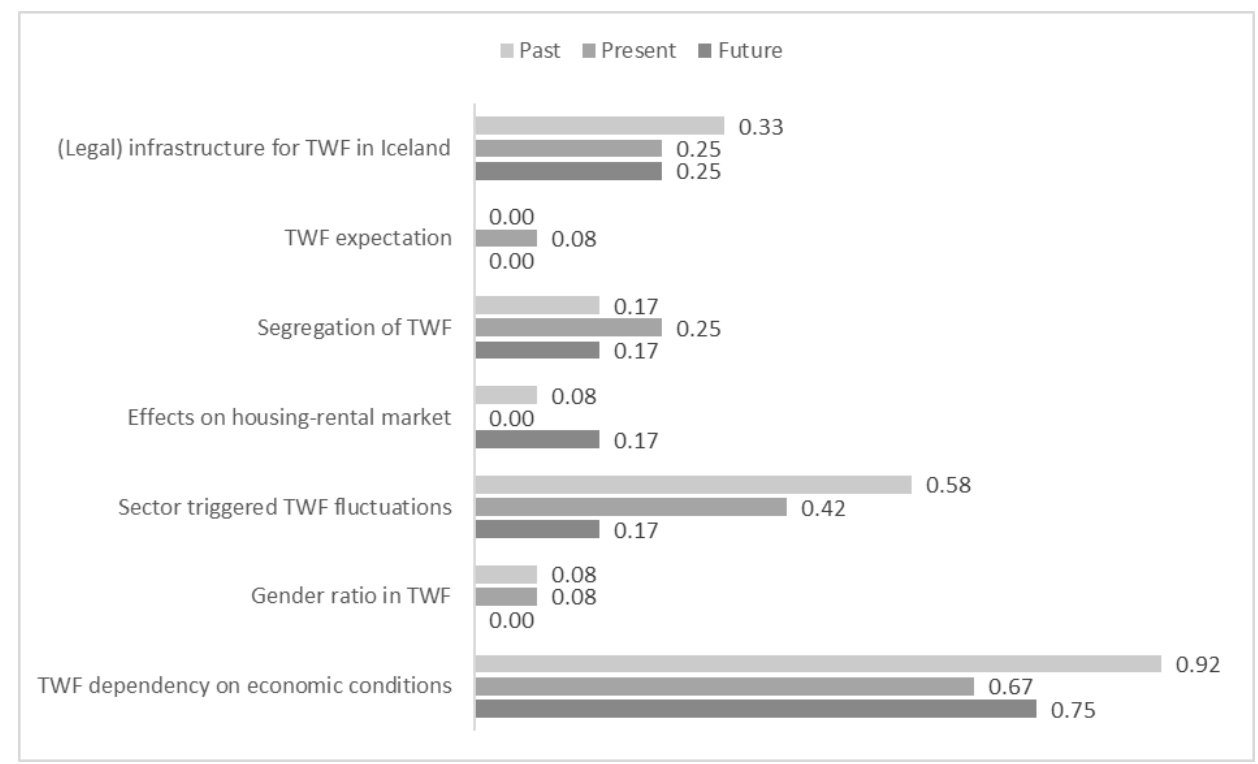

Figure 3. Descriptive statistics for the seven themes indicating how much they are emphasized in regard to past, present and future 


\section{Results}

A few of the themes generated from the expert comments, although interesting, received lower inter-rater emphasis. These themes are: Effects on bousing/rental market, Segregation of temporary workforce, Gender ratio in temporary workforce, and Expectations of temporary workforce employees.

Effects on housing/ rental market was given more emphasis when talking about the past, but less when focusing on the present and future. Considering the wide coverage of this topic in general media in Iceland, one would expect experts to put more emphasis on the topic. Another theme that emerged, however, also with low inter-rater emphasis was Segregation of the temporary workforce, which most often occurs due to the language barrier "a lot of these employees are from countries such as Romania and Bulgaria, who don't speak any Icelandic or English, and are therefore unable to find information", as well as geographical isolation and reliance on employer "... are in a very isolated situation, especially in remote locations, hotels and such in the countryside, they are in no connection with the Icelandic community except through their employer, which means they are totally reliant upon him to fulfill his duties" (Expert 3). Experts identified the Gender ratio in temporary workforce, as one of the aspects describing the market. They indicated that ten or so years ago primarily men were coming for temporary work in Iceland, mainly in the construction sector. However today the situation is changing, partially due to the increase of jobs in the tourism industry. Yet another theme that emerged was Expectations of temporary workforce employees, typically related to better economic conditions "majority of people arriving to Iceland are looking for higher salary and cheaper living, but they are not oriented to long term work in Iceland" (Expert 1).

However, the three most pronounced themes with the highest inter-rater agreement were: Temporary workforce dependency on economic conditions in Iceland, Sector triggered temporary workforce fluctuation and socio-legal infrastructure for temporary workforce in Iceland. These themes reflect the most important aspects of the temporary staffing market in Iceland, as seen by experts, and are discussed in-depth below.

\subsection{Temporary workforce dependency on economic conditions}

This theme was well expressed and had the highest emphasis among experts when describing the temporary staffing market in Iceland, particularly when talking about developments in the past. Experts indicated that overall economic conditions in the country impact the fluctuations in temporary workforce in Iceland. Certain interfering conditions, e.g. the financial crisis of 2008 , have had negative impact, while on the other hand the growing economy is directly reflected in the growing numbers of temporary workforce in the country:

"The current situation in the labor market is similar to the boom years before the economic collapse. A serious labor shortage, undermanned workplaces, and large influx of foreign workers into the country." (Expert 5) 
"It died out in the wake of the economic collapse and no workers were coming to Iceland through temporary staffing agencies for a number of years. In the past few years the numbers of temporary staffing agencies and TSA workers have again increased rapidly." (Expert 2)

"Clearly the development of TSAs has in many ways been steps ahead of the firms. The labor market has gone through rapid development in recent years and the labor shortage has been pronounced." (Expert 11) "The foreign workforce here has been growing since 2011 in direct correlation with the labor shortage that Icelandic companies have been experiencing.” (Expert 6)

"The size of the foreign workforce in Iceland will undoubtedly increase in coming years. Especially among unskilled workers and to some extent among workers with vocational training." (Expert 4)

Experts indicated that in periods of economic growth, the temporary workforce provided through agencies meets the needs of firms for additional workforce and contributes to the continuity of economic growth in the country, providing the flexibility to meet these fluctuations:

"For the past year we have seen a lot of tension in the labor market and I feel that many employers are starting to show signs of fatigue. It's difficult to get competent workers and even more difficult to retain them ... I believe that in the next year and the year thereafter we will see a slow-down in the economy that will relax some of this tension." (Expert 11)

"The main reasons why firms are now contracting with TSAs are e.g. because of the overheated economy and minimal unemployment, which necessitates the import of foreign workers. Most firms utilize the services of TSAs for the short term to meet seasonal demands." (Expert 12)

Experts also identified a changing landscape in regard to competences and skills needed and how foreign workforce contributes in meeting these market needs:

"Many people are saying that the generations entering the Icelandic labor market are coddled and utterly inexperienced and devoid of any understanding of how the economy works. Many employers say that the foreign workforce is much more efficient and diligent." (Expert 11)

The role of TSAs in the temporary workforce market in Iceland is seen as very visible, however experts were hesitant in their future forecasts for such agencies as players in the Icelandic market, relating it to broader economic developments in the country: 
"Regarding the future of such organizations I think it always depends on the economy of the country $<\ldots>$ I think, the future of such organizations depends on many things, but the main thing is how they manage to keep the wages of the workers working through the agencies close to the wages received by the workers working directly at the companies." (Expert 1)

"On the other hand, it is clear that the wage increases over the past few months have had an effect on the economy and if [collective agreements will lead to] further increases in the near future, then companies' demand for labor will change." (Expert 6)

"In the coming months and years the demand for foreign labor is expected to decrease as the economic growth will slow down and labor market activities decline. Thus we can expect that a certain level of equilibrium is being reached in the influx of foreign nationals for work in Iceland." (Expert 2)

However, the experts do not doubt that the TSAs will continue to be a workforce provider in the market, serving the companies. Importantly though, when it comes to the agencies, their reputation and ability to meet clients' needs regarding the competence of the temporary workforce, is seen as a key factor for temporary staffing agencies:

"TSAs are here to stay and will only become more professional and their services will be utilized to a much greater extent than currently." (Expert 11)

"The future of TSAs depends on them maintaining a good reputation and not being found to mistreat employees. The client firms do not want to be associated with such operations." (Expert 12)

Overall, the experts identify the strong impact of economic booms and busts on the Icelandic temporary staffing industry. They also acknowledge the interplay of the two, and how the temporary staffing industry can provide the needed flexibility to support economic growth and buffer when demand falls off. Finally, they identify that the agencies have a clear role in the labor market, but only as far as they uphold professional standards in the treatment of their workforce and maintain their reputation.

\subsection{Sector triggered temporary workforce fluctuation}

This category was also well expressed in expert comments in regard to temporary workforce development in Iceland, particularly visible in the past. Overall developments of temporary work force in Iceland, as seen by experts, is often triggered by very high need of additional manpower in certain sectors, e.g. construction: 
"The number of temporary staffing agencies and their workers increased significantly in the years before the economic collapse, primarily as a result of tremendous growth in construction.” (Expert 2)

"At the beginning of 2017 there were fewer than a thousand temporary agency workers in Iceland, so their numbers have clearly been growing very fast this year. Workers who arrive through temporary staffing agencies are predominantly coming to work in the construction sector." (Expert 2)

"There is considerable excess demand for workers in specific sectors, especially in tourism and construction.” (Expert 6)

"There is a great demand for unskilled workers and people in tourism and in the construction sector. The demand for skilled workforce is much lower." (Expert 4)

Sector triggered fluctuation is also forecasted for the future, however relating it with more knowledge-intensive sectors, such as healthcare:

"Whether it will be because of developments in currency exchange rates, collective agreements or domestic issues, I expect that the share of temporary staffing agencies will slowly decrease here in Iceland. However, it is difficult to predict since some sectors face constant challenges when it comes to adequate labor supply, for example the health care sector and related service-jobs where temporary work agencies could blossom for the long term." (Expert 6)

Overall, the experts recognize the demand-side impacts on the temporary workforce with the growth of certain sectors creating a clear market for temporary staffing agencies in Iceland. Different sectors require differently-skilled staff, and for the future Iceland may experience a shortage of skilled workers in sectors like healthcare.

\subsection{Social infrastructure for temporary workforce}

This category was consistently expressed a long timeline of temporary workforce development in Iceland, even though somewhat higher emphasis was put on the past:

"...the Icelandic legislation and environment must take into consideration and verify that temporary staffing agencies operating in Iceland are following the law." (Expert 5)

"Therefore the greatest challenge is to reach these people, to best ensure their working conditions and standard of living and increase their possibilities to adapt to the Icelandic society, whether they are here for the short term or the long term." (Expert 3) 
"We must also bear in mind that along with this great influx of workers also come families and children in many cases. The school system needs to be better prepared for this, especially in communities where the increase is significant." (Expert 5)

"Temporary staffing agencies are one part of globalization and therefore it is likely that they are here to stay. This entails significant challenges when it comes to safeguarding working conditions. The housing shortage comes into play here, as temporary agency workers are in a way indentured servants. Excessive amounts are often charged for driving them to and from work and all sorts of costs are deducted from their paychecks, which is unheard of when Icelanders are hired." (Expert 9)

"I expect that since using temporary staffing agencies appears to be very profitable for Icelandic firms it will continue to increase until we will drown in immigration problems of the worst sort seen in Europe up until now. This will be followed by changes in politics, culture etc." (Expert 8)

Overall, the experts identify the problematic aspects that may accompany the societal impact of the temporary staffing industry, as well as the risks to the workers and their families. This is a challenge for the state and the community, as well as for the labor market.

\section{Discussion}

The historical overview of the Icelandic labor market showed that the appearance of TSAs in the early 2000's was facilitated by a booming economy, serious labor shortages in a specific sector (construction) and a fairly unregulated labor market. The TSAs disappeared as quickly as they had appeared when the economy collapsed and the labor demands of the construction sector dried up. While one cannot preclude that the enactment of the Act on Temporary Work Agencies No. 139/2005 could have been a contributing factor in the collapse of the TSA market, the reappearance of the TSA market in recent years indicates otherwise. With the resurging economy and thriving tourism industry the construction sector has taken off again and TSAs are again prospering in the Icelandic labor market. While the pattern of growth in Iceland is somewhat similar to what has occurred in other countries, such as in Australia (Coe, Johns \& Ward 2008), Germany (Ferreira 2016) and Norway (Jordhus-Lier, Coe \& Braten 2015), the volatility is much greater and the composition of the temporary agency workforce is different, or exclusively foreign nationals.

The results from the expert opinion research indicate that temporary staffing agencies that maintain a good reputation will be a common workforce provider in the market, serving the needs of firms in the future. The most important theme among the experts: 
temporary workforce dependency on economic conditions in Iceland indicates that the economic conditions in Iceland have the most significant effect on the fluctuation of temporary workforce in Iceland.

The situation in the Icelandic labor market today is similar to the boom years before the economic collapse of 2008 with labor shortage, undermanned workplaces, and large influx of foreign workers into the country. Thus due to the rapid decline of unemployment in Iceland from 2009-2010, the number of foreign workforce has been growing in correlation with the labor shortage that Icelandic companies have been experiencing (Rúv 2017a). The current economic growth has created tension in the labor market and it is difficult to recruit competent workers and harder to retain them.

Employers question the readiness of generations entering the Icelandic labor market today and whether they have the motivation, experience and understanding necessary in a competent workforce. At the same time, they view the foreign workforce as much "more efficient and diligent". While this view of migrant workers is in line with the 'good worker' rhetoric (MacKenzie \& Forde 2009) it also indicates that the TSAs may increasingly be in a position to supply the preferred labor force for the needs of the Icelandic labor market. It is not clear from the findings whether the TSAs in Iceland have played an active role in producing this image of migrants (Findlay et al. 2013), but this is an interesting finding that needs to be examined further.

The future of the TSAs seems to depend on the economy of the country, how they manage to keep the wages of the TSA workers close to the wages received by the workers working directly at the companies. But in many cases workers that come to Iceland through TSAs get paid less than the locals (ASÍ 2018). In addition, the wage increases over the past few months have had an effect on the economy and can impact the demand for labor. The findings indicate that the demand for foreign labor is expected to decrease as the economic growth will slow down and labor market activities decrease. Thus, a certain level of equilibrium can be expected in the influx of foreign nationals for work in Iceland. TSAs will remain in Iceland but become more professional.

The second theme, Sector triggered temporary workforce fluctuation, indicates that the significant increase in the number of TSAs has primarily been a result of the tremendous growth in construction and most recently, tourism. Workers who arrived through TSAs were predominantly coming to work in the construction sector and the economic boom lead to a massive increase in demand for construction workers in the years 2002-2007 and again as the economy has been recovering since 2011. The tourism industry has seen unprecedented growth in the past few years, leading to a labor shortage that has increasingly been met through the hiring of TSA workers, but also by direct hiring of foreign migrants. The demand for workers in tourism is mainly for unskilled workers, but since competency in the Icelandic language is not a consideration in dealing with the international clientele in the sector, foreign nationals can increasingly be found in higher level positions. The experts forecast some slow-down in the growth of these sectors, but most of them foresee a continued demand for workers beyond what the Icelandic labor market can supply. 
The demand for skilled workforce is much lower but may be changing in the future. The experts point out that the sector that may see excess demand for a skilled workforce in the future is healthcare. The shortage stems in part from the Icelandic education system not being able to meet the demands for e.g. nurses and orderlies. At least two temporary staffing agencies operated in the healthcare sector before the economic collapse, setting a precedent for the use of these services by the Icelandic state (Blöndal 2005). Like many other sectors, the healthcare sector faces constant challenges when it comes to adequate labor supply, making it a sector where TSAs could blossom for the long term.

The third theme, social infrastructure for temporary workforce indicates that TSAs are here to stay. Thus, the Icelandic legislation and environment need to take into consideration and verify that TSAs operating in Iceland are following the law. This entails significant challenges when it comes to safeguarding working conditions. Unfortunately, the TSAs in Iceland seem to be able to pay the foreign workers less than locals, as seems to be the rule in neighboring countries as well (Friberg 2013).

The experts point out that the influx of foreign workers exacerbates the housing shortage and poses great challenges such as ensuring that migrants' working conditions and standard of living are equal to what the locals have. Moreover, their possibilities of workers and their families to adapt to and participate in the Icelandic society, whether they are here for the short term or the long term, need to be increased. The experts emphasize the importance of creating socio-legal structures in society, informing workers about their rights, lessening their dependence on their employer and of preventing social segregation.

\section{Conclusion}

The turmoil in the Icelandic economy since the first years of the new millennium has significantly changed the local labor market. It now relies to a far greater extent than before on access to temporary foreign workers, often brought to Iceland by TSAs. This has introduced considerable segmentation to the labor market, with the foreign workers being paid significantly less than their local counterparts, often being offered terms for lodging, fees and more that the latter would not accept.

Although this development reflects conditions in Iceland in this period similar changes can be seen in the neighboring countries on both sides of the Atlantic. The changes in Iceland have though taken place at an extremely rapid pace. This probably reflects on the one hand the relative isolation of the Icelandic labor market before the country joined the EEA and on the other the extreme swings in the demand for labor, in particular unskilled labor, in the last decade and a half.

These dramatic changes to the Icelandic labor market have undoubtedly had a significant impact on Icelandic society (e.g. school system, housing system, language, and culture) but there is surprisingly little research available into this.

Although the rise of the TSAs could possibly to some extent be reversed by a significant dip in demand for labor in Iceland the phenomenon seems to have gained such 
a powerful foothold in Iceland that this would not mean the end of the TSAs in the country. As long as there is economic rationale for their operation and a legal and regulatory framework that accommodates them they can be expected to continue bringing temporary staff to Iceland. The impact on the labor market and society thus seems likely to be permanent.

Such a development certainly calls for research into its impact and on whether this calls for a greater response by Icelandic institutions including but not limited to the legislative branch, unions and the education system.

\section{Notes}

1 The Central Bank of Iceland measures the so-called output gap of the economy, a measure of over-heating or under-utilization of resources. It has been rising steadily since 2010, when it was negative (under-utilization of resources, e.g. high unemployment) and peaked at a positive (overheating) $3.3 \%$ of potential output in 2016. It has since decreased and was $1.8 \%$ of potential output in 2017. The Central Bank attributes this, in part, to large scale importation of labor (Central Bank of Iceland 2018).

2 Data from those two periods on the number of agencies and workers is unfortunately not easily comparable as the legislation requiring the registration of the agencies did not come into effect until towards the end of the pre-crisis boom.

3 In the year $187080 \%$ of the Icelandic labor force was still working in agriculture, $10 \%$ in fisheries and another 10\% in all other sectors (Statistics Iceland n.d.). This meant that in practice there was little room for meeting the cyclical needs of the agricultural sector for workers by recruiting them temporarily from other sectors. It was though to some extent possible for agricultural workers to seek temporary employment in the also cyclical fisheries sector. In the decades that followed, the share of agriculture in employment declined rapidly, below $50 \%$ by 1910 and to $25 \%$ by 1950 . The share of the labor force working in fisheries doubled between 1870 and 1930, to $20 \%$ but has since slowly declined.

4 A report by Arbeidsliv i Norden (Wallin 2013) notes that the proportion of Icelanders aged 15-19 that are employed (most of them part-time while also in school) was $52 \%$ in 2013, considerably higher than in the other Nordic countries. The second highest ratio for this age group was in Denmark $(44 \%)$ and the lowest in Sweden (16\%).

5 In the period 1986-2016 70.126 Icelandic citizens migrated to the other Nordic countries (Denmark, Faroe Islands, Finland, Norway and Sweden) while 57.909 Icelandic citizens migrated in the other direction, for a net outflow of 12.217 from Iceland. At the same time only 11,427 foreign citizens (not all of them Nordic) migrated from the Nordic countries to Iceland and 10,788 migrated in the other direction, leading to a net inflow of 639 to Iceland. Source: Statistics Iceland and authors' calculations.

6 The importance of foreign workers to meet the demand for low-skilled labor can e.g. be seen by looking at the proportion of members of unions by nationality. Foreigners are $45 \%$ of the members of Efling, 54\% of VSFK and 30\% of Hlíf. (ASÍ 2018). All three unions primarily serve workers in low-skilled jobs.

7 In 2009 average hourly wages in Norway, measured in euros, were 116\% higher than in Iceland. By 2016 the difference had shrunk to $24 \%$. Source Eurostat and authors' calculations.

8 Data on the break-down of workers by the type of contract they had is unfortunately not available for this period. It is however known that many foreigners working on the projects in Eastern Iceland, in particular Chinese nationals, had a direct contractual relationship with their employer, while others were employed by TSAs. Besides the Portuguese agencies, several other agencies sent construction workers, mainly from Eastern Europe, to Iceland at the time. 
9 The earliest use of the Icelandic term for temporary work agency (starfsmannaleiga) that can be found (in March 2018) in the database of timarit.is is from the year 2000. An article from that year discusses "so-called temporary work bureaus" that had then started operating in the other Nordic countries (Verktækni 2000 p. 7). The term then appears again in the database in 2003 and frequently in the following years, usually referring to agencies working on the Kárahnjúkar project.

10 Source for statistics on workers, temporary work agencies and service bureaus for posted workers is Vinnumálastofnun (e. Directorate of Labor). Note that the figures for workers are totals for each year, on average at a given point of time the number of workers in the Icelandic labor market coming through these channels was lower.

11 A posted worker is an employee who is sent by his employer to carry out a service in another country on a temporary basis. Within the EEA area, directives 96/71/EC and 2014/67/EU address issues concerning the posting of workers.

12 Statistics Iceland estimates that tourism and related sectors employed 27,200 people in Iceland in 2017 , more than twice the number in 2008, when 12,300 people were employed. The construction sector has been adding workers at a rapid pace since 2012 (going from 9,300 in 2012 to 11,800 in 2016) even if employment in that sector has not yet reached the pre-crisis peak (17,500 in 2008). Both sectors disproportionally rely on temporary foreign workers. This makes it likely that many of them are missing in the labor market survey conducted by Statistics Iceland so the growth in employment may be even higher than these figures indicate.

13 The CEO of the Directorate of Labor in Iceland estimates that up to one third of TSAs or service bureaus do not adhere to contracts established by unions despite the legal obligation (RÚV 2017a).

14 The survey (Efling 2017) was done on behalf of four unions with a large number of foreign members working in low skilled jobs. It did not explicitly ask about nationality but was offered in three languages, Icelandic, Polish and English. The figures reflect the difference in answers between those that answered the Icelandic version and those that answered the English or Polish version.

15 In addition, the Icelandic educational system does not seem to be dealing very well with the challenge of educating children whose native language is not Icelandic. They do significantly worse than their counterparts in tests and are less likely to seek higher education. This gap is larger in Iceland than in the other Nordic countries (Nordic Council of Ministers 2018).

\section{References}

ASÍ (2018). “Íslenskur vinnumarkaður: Mars 2018”. Retrieved from http://www.asi.is/media/314075/ ny-vinnumarkadsskyrsla-2018.pdf

ASí and SA (2004). "Samkomulag um útlendinga á íslenskum vinnumarkaði”. Retrieved from http:// www.skirteini.is/wp-content/uploads/pdf/Samkomulag-7.a_mars_2004.pdf

ASÍ and SA (2018). "Samkomulag milli Alpýðusambands Íslands og Samtaka atvinnulífsins um eftirlit mеð launum og starfskjörum starfsmanna starfsmannaleiga, ábyrgð notendafyrirtækja og sérstaka viðurkenningu starfsmannaleiga". Retrieved from http://www.asi.is/media/314192/samkomulagasiogsa-um-starfsmannaleigur.pdf

Blöndal, E. (2005). Starfsmannaleigur: Greinargerd unnin fyrir félagsmálaráduneytid. Bifröst: Rannsóknarsetur vinnuréttar og jafnréttismála. Retrieved from https://www.stjornarradid.is/media/velferdarraduneyti-media/media/acrobat-skjol/Starfsmannaleigur.pdf

Bryman., A., and Bell, E. (2007). Business Research Methods (2n ed.). Oxford: OUP.

Central Bank of Iceland (2018). "Monetary Bulletin 2018/1". Retrieved from https://www.cb.is/library/Skraarsafn---EN/Monetary-Bulletin/2018/February-2018/MB_2018_1.pdf

Coe, N.M., Johns, J., and Ward, K. (2008). "Agents of casualization? The temporary staffing industry and labour market restructuring in Australia", Journal of Economic Geography 9(1), 55-84.

Coe, N.M., Johns, J., and Ward, K. (2009). "Managed flexibility: labour regulation, corporate strategies and market dynamics in the Swedish temporary staffing industry", European Urban and Regional Studies, 16(1), 65-85. 
Coe, N.M., and Ward, K. (2014). "The creation of distinctive national temporary staffing markets", in J. Fudge and K. Strauss (eds.), Temporary work, agencies and unfree labour: Insecurity in a new world of work. New York, NY: Routledge.

Creswell, J.W. (1998). Qualitative Inquiry and Research Design: Choosing Among Five Traditions. Thousand Oaks, CA: Sage Publications.

Directorate of Labor (n.d.). "Foreign workers". Retrieved from https://vinnumalastofnun.is/en/foreign-workers

Efling (2017). "Vinnutíminn styttist á sama tíma og laun hækka umtalsvert - Ný Gallup könnun". Retrieved from https://efling.is/2017/11/27/vinnutiminn-styttist-a-sama-tima-og-laun-haekkaumtalsvert-ny-gallup-konnun/

Eichhorst, W. (2015). "The Unexpected Appearance of a New German Model”, British Journal of Industrial Relations 53, 49-69. doi:10.1111/bjir.12055

Eurofound (2015). "Sixth European Working Conditions Survey: 2015". Retrieved from https://www. eurofound.europa.eu/surveys/ european-working-conditions-surveys/sixth-european-workingconditions-survey-2015

Faccini, R. (2014). "Reassessing Labour Market Reforms: Temporary Contracts as a Screening Device", Economic Journal 124, 167-200. doi:10.1111/ecoj.12072

Ferreira, J. (2016). "The German temporary staffing industry: growth, development, scandal and resistance", Industrial Relations Journal 47(2), 117-143.

Findlay, A., McCollum, D., Shubin, S., Apsite, E., and Krisjane, Z. (2013). "The role of recruitment agencies in imagining and producing the 'good' migrant", Social \& Cultural Geography, 14(2), 145-167.

Fréttablaðið (2014). "Kvensjúkdómalæknir í vinnu á leikskóla í átta ár”, 14(280), Nov. 28.

Friberg, J.H. (2013). "Comparative analysis and conclusions”, in J.H. Friberg and L. Eldring (eds.), Labour migrants from Central and Eastern Europe in the Nordic countries: Patterns of migration, working conditions and recruitment practices. Copenhagen: Nordic Council of Ministers.

Friberg, J.H., Arnholtz, J., Eldring, L., Hansen, N.W., and Thorarins, F. (2014). "Nordic labour market institutions and new migrant workers: Polish migrants in Oslo, Copenhagen and Reykjavik", European Journal of Industrial Relations 20(1), 37-53. doi:10.1177/0959680113516847

Gundert, S., and Hohendanner C. (2014). "Do fixed-term and temporary agency workers feel socially excluded? Labour market integration and social well-being in Germany", Acta Sociologica 57(2), 135152. doi:10.1177/0001699313496588

Gwet, K. (2002). Handbook of Inter-Rater Reliability. Gaithersburg, MD: STATAXIS Publishing.

Hardy, J., Eldring, L., and Schulten, T. (2012). "Trade union responses to migrant workers from the 'new Europe': A three sector comparison in the UK, Norway and Germany”, European Journal of Industrial Relations 18(4), 347-363.

Jahn, E.J., and Rosholm, M. (2013). "Is temporary agency employment a stepping stone for immigrants?”, Economics Letters 118(1), 225-228. doi:10.1016/j.econlet.2012.10.029

Jahn, E.J., and Rosholm, M. (2014). "Looking beyond the bridge: The effect of temporary agency employment on labor market outcomes", European Economic Review, 65, 108-125. doi:10.1016/j.euroecorev.2013.11.001

Jordhus-Lier, D., Coe, N.M., and Bråten, S.T. (2015). “Contested growth: the development of Norway's temporary staffing industry”, Geografiska Annaler: Series B, Human Geography 97(1), 113-130.

Katz, L.F., and Krueger, A.B. (2016) The Rise and Nature of Alternative Work. Arrangements in the United States, 1995-2015. NBER Working Paper No. 22667. September. Retrieved from http://www.nber. org/papers/w22667

Krueger, T., Page, T., Hubacek, K., Smith, L., and Hiscock, K. (2012). "The role of expert opinion in environmental modelling", Environmental Modelling \& Software 36, 4-18.

MacKenzie, R., and Forde, C. (2009). "The rhetoric of the 'good worker' versus the realities of employers' use and the experiences of migrant workers", Work, Employment and Society 23(1), 142-159. 
Mahmoud, R. (n.d.). A Review of the Expert Opinion Technique and Recommendations to Reduce its Bias. White paper. Retrieved from http://www.format-project.eu/deliverables/white-papers/january-2015-areview-of-the-expert-opinion-technique-and-recommendations-to-reduce-its-bias/at_download/ file

Muskat, M., Blackman, D.A., and Muskat, B. (2012). "Mixed methods: Combining expert interviews, cross-impact analysis and scenario development", The Electronic Journal of Business Research Methods 10(1), 09-21.

Nordic Council of Ministers (2018). "State of the Nordic Region 2018”. Retrieved from http://norden. diva-portal.org/smash/record.jsf?pid=diva2\%3A1180241\&dswid=8969

Porter, A.L., Cunningham, S.W., Banks, J., Roper, A.T., Mason, T.W., and Rossini, F.A. (2011). Forecasting and management of technology. New York, NY: John Wiley.

Rowe G., and Wright G. (2001). "Expert Opinions in Forecasting: The Role of the Delphi Technique", in: J.S. Armstrong (ed.), Principles of Forecasting. International Series in Operations Research \& Management Science. Boston, MA: Springer.

RÚV (2017a). “Tiltölulega auðvelt að blekkja stjórnvöld”, Spegillinn, 10 May. http://www.ruv.is/frett/ tiltolulega-audvelt-ad-blekkja-stjornvold

RÚV (2017b). "Detta er kannski ekki íslenskur standard", Spegillinn, 23 May. http://www.ruv.is/frett/ thetta-er-kannski-ekki-islenskur-standard

Statistics Iceland (n.d.). "Migration". Retrieved from https://www.statice.is/statistics/population/migration/

Thorarins, F. (2013). "The rise and fall of temporary staffing agencies in Iceland”, in J.H. Friberg and L. Eldring (eds.), Labour migrants from Central and Eastern Europe in the Nordic countries: Patterns of migration, working conditions and recruitment practices. Copenhagen: Nordic Council of Ministers.

Verktækni (2000). Vinnutimi og starfsmannaleiga, 6(7).

Wallin, G. (2013). "Växande antal deltidsjobb ger sämre arbetsmiljö för unga", Arbeidsliv I Norden, 9 October. Retrieved from http://arbeidslivinorden.org/i-fokus/i-fokus-2013/arbetsmiljoen-foerunga/article.2013-10-07.2742112816 
